DOI: $10.19195 / 0867-7441.23 .11$

\title{
Anna Wiśniewska
}

Uniwersytet Wrocławski

\section{Córka cieni — od typologii sieroty i children studies do pamięci protetycznej i memory boom}

Jesteśmy tym, kim pamiętamy, że jesteśmy.

E. Casey ${ }^{1}$

Słowa kluczowe: sierota, poszukiwanie tożsamości, wpływ historii

Keywords: orphan, searching of identity, influence of history

Trylogia Córka cieni (2016) autorstwa Ewy Cielesz opisuje życie sieroty wojennej Juliany Dors i jej bliskich. Tłem cyklu są wydarzenia historyczne z czasów II wojny światowej, PRL-u, lat 90. XX i pierwszego dziesięciolecia XXI w. Fabułę powieści łączą dwie postaci - wymieniona protagonistka oraz Adam, absolwent historii. Utwory noszą cechy powieści obrachunkowej ${ }^{2}$ znanej $z$ drugiej połowy ubiegłego stulecia - zawierają ocenę deformacji systemu PRL-u, wymieniają błędy aparatu władzy oraz opisują losy pokolenia doświadczonego przez konflikt zbrojny.

W niniejszym szkicu zostanie przedstawiona typologia sieroty, dziecka opuszczonego — bohatera żyjącego w XX i XXI w. - egzemplifikowana postaciami Juliany, jej córki Joanny oraz krewnej Teofili. Wspomnienia protagonistki staną się asumptem do rozważań nad jej dzieciństwem w nurcie badań children studies. Jed-

${ }^{1}$ Cyt. za: T. Skalska, Między pamięcia protetyczna a protezami pamięci. Dyskursy kultury popularnej w kontekście memory boom, Łódź 2015, b.s., http://dspace.uni.lodz.pl:8080/xmlui/handle/11089/12197 (dostęp: 18.04.2017).

2 S. Burkot, Literatura polska w latach 1939-1999, Warszawa 2002, s. 191. 
nocześnie przytaczane zdarzenia oraz refleksje zostaną zaprezentowane zarówno w świetle koncepcji pamięci protetycznej Alison Landsberg, jak i memory boom, opisanego przez Andreasa Huyssena i Dawida Berlinera.

Cykl powieści obyczajowych Cielesz składa się z tomów: Siedem szmacianych dat, Obce matki, Burza przed cisza (Warszawa 2016). Dla trylogii charakterystyczne staje się rozbicie narracji między pamiętnikarską a autorską. Pierwsza z nich jest używana, gdy czytelnik zapoznaje się z dziennikiem Magdaleny — matki protagonistki — oraz wspomnieniami Juliany. Natomiast dzięki drugiej odbiorca zostaje zaznajomiony z życiem Adama, Teofili i pozostałych postaci. Następnym wyróżnikiem są tytuły znaczące. Część rozpoczynająca serię przybliża dzieciństwo głównej bohaterki przedstawione w rękopisie znalezionym w chacie. Dziewczynka na każde urodziny dostawała lalkę uszytą przez rodzicielkę z jej starej sukienki. Kukiełki symbolizują lata przeżyte w bieszczadzkiej głuszy. Natomiast „obce matki” to kobiety, które — z różnym skutkiem — starają się zaopiekować sierotą. Prawdziwy dom — ostoję i personifikację poczucia bezpieczeństwa - stwarza jej dopiero babka Olena. Ostatni tom rozpoczynają wspomnienia Dors o tej postaci i prezentacja adolescencji oraz dorosłości sieroty. Rozważania przeplatają opisy zdarzeń z czasów współczesnych — kolejne kłopoty Teofili, relacje tudzież konflikty między bohaterami utworu; równolegle to etap przepracowania traum młodości przez kobietę. Jak wskazuje tytuł — dość burzliwy. Kończy się śmiercią Juliany na grobie jej rodziców — po emocjach ostatnich miesięcy następuje cisza żałoby Joanny po stracie matki.

W pierwszej części niniejszego szkicu zostanie zaprezentowana typologia sieroty — dziecka opuszczonego, bohatera osadzonego w realiach XX w. ${ }^{3}$ Proponuję podział na trzy sposoby realizacji tego motywu: (1) „sierota wędrująca szuka”, (2) „dorosła sierota opowiada” oraz (3) „dziecko rozwodników”. W pierwszym z nich można wyróżnić kategorie: „niewinność uciśniona”, „sierota przygarnięta pomaga”, bohater „nie wie, że jest sierotą”, sierota w domu dziecka”, „dziecko ulicy”; postaci często towarzyszy też „opiekuńczy duch matki”.

Motyw sieroty realizuje protagonista, który stracił oboje rodziców i szuka opiekuna lub kogoś, kto zdecyduje się go wychować. Konflikty międzynarodowe XX i XXI w. przyczyniły się do wzrostu frekwencji tego typu bohatera w powieści obyczajowej. Coraz rzadziej ma on określony zestaw cech. Często stara się samowychować ${ }^{4}$, poradzić sobie w obliczu trudnej sytuacji. Nie wierzy już tak w opiekę Jezusa i aniołków ${ }^{5}$, odczuwa odpowiedzialność za swój los.

${ }^{3}$ Omawiany typ bohatera opisała Magdalena Jonca w monografii Sierota $w$ literaturze polskiej dla dzieci w XIX wieku (Wrocław 1994). Jednak ze względu na odmienny zakres tematyczny (literatura dla dzieci) oraz przemiany w postrzeganiu dziecięcości na przestrzeni ostatnich lat pozostanę jedynie przy zasygnalizowaniu stanu badań nad toposem.

${ }^{4}$ M. Jonca, op. cit., s. 288.

5 Ibidem, s. 294. 
„Dorosła sierota opowiada” o swoim losie najczęściej tuż przed śmiercią. Jest to rodzaj rozliczenia z przeszłością, przepracowania trudnych sytuacji i kompleksów. Nierzadko potrzebuje rozmowy z inną osobą, często o wiele młodszą od siebie, lub uważa za nią czytelnika. Wariant możemy spotkać choćby w Brygidzie Marii Krüger (1979) lub w powieści Jerzego Pietrkiewicza Anioł ognisty, mój aniot lewy (1993).

Wariantem bohatera sierocego, bardzo częstym w literaturze polskiej powojennej, jest „sierota wędrująca szuka”. Czego? Domu, miłości, opieki, poczucia bezpieczeństwa, zainteresowania — wszystkiego tego, co straciła wraz ze śmiercią rodziców. Warto przyjrzeć się protagonistom Telemacha $w$ dżinsach (1979) Adama Bahdaja czy Ireny Jurgielewiczowej: O chłopcu, który szukat domu (1947); Tego obcego (1961); Innej? (1975). Ze względu na obszerny materiał badawczy wariant wymaga podzielenia na następujące kategorie:

— „niewinność uciśniona” cierpi z powodu prześladowcy, zło jednak zawsze zostaje ukarane, np. Maria Buyno-Arctowa, Stoneczko (1920); Ferdynand Ossendowski, Wacek i jego pies (1947);

— „sierota przygarnięta pomaga”, odwdzięczając się nowym opiekunom, przemienia bohaterów, sprawiając, że w nowym miejscu zamieszkania znów gości dawno zapomniane szczęście. Postać najczęściej jest płci żeńskiej. Spotkamy ją również w Stoneczku Buyno-Arctowej, ponadto w Pannie z mokra głowa (1933) Kornela Makuszyńskiego, Złodziejach snów (2008) Małgorzaty Strękowskiej-Zaremby czy O jednej Anielce (1917) Zofii Kowerskiej;

— czasami zdarza się osobliwa sytuacja — bohater ,nie wie, że jest sierotą”. Dotyczy to półsierot, które nie zostały poinformowane o śmierci drugiego rodzica lub nie przyjmują tego do wiadomości, np. Timothée de Fombelle, Tobi Lolness (2008); Marcin Szczygielski, Arka czasu, czyli Wielka ucieczka Rafała od kiedyś przez wtedy do teraz $i$ wstecz (2015);

— „sierota w domu dziecka” opisuje życie w placówce wychowawczej. Najczęściej relacja nie napawa optymizmem, wszystko zależy od opiekunów, a dyrektor czy kierownik uosabia zło biurokracji/systemu politycznego/zacofania i braków w wychowaniu pedagogicznym. Ocaleniem przed wrogim systemem okazuje się ucieczka w poszukiwaniu własnych korzeni. W ten nurt wpisują się bohaterowie utworów: Natalii Rolleczek Drewniany różaniec (1953) i Oblubienice (1956), Doroty Terakowskiej W krainie kota (1999), Iwony Chmielewskiej Pamiętnik Blumki (2011);

— „dzieci ulicy” mogą kojarzyć się ze wschodnim bezprizornymi. Pojawiają się zwykle po wojnie, nie chcą trafić do sierocińca i starają się przetrwać do następnego dnia. Ze zrozumiałych względów nie dbają o higienę, kradną, często popadają w konflikt z prawem. Czasami trafiają na ulicę spośród „dzieci opuszczonych", z rodzin niewydolnych wychowawczo, gdyż bycie w grupie daje im poczucie bezpieczeństwa. Występują w utworach Chtopiec z Salskich Stepów 
(1949) i Archipelag ludzi odzyskanych (1968) Igora Neverlego, lecz także w Stawiam na Tolka Banana (1967) Adama Bahdaja;

— ostatnim wariantem są „dzieci rozwodników”, a także „opuszczone” w niemowlęctwie przez ojca. Motyw coraz częściej występuje w literaturze, szczególnie dla dzieci i młodzieży. Być może stanowi odpowiedź na obecną sytuację w Polsce i za granicą. Małżeństwo z różnych względów przeżywa kryzysy, które kończą się rozwodem. Ofiarami tej sytuacji są dzieci. Wychowane przez jednego z rodziców przeżywają trudną sytuację, próbują odnaleźć się w uboższej rzeczywistości, najczęściej nie potrafią nawiązać relacji z tym, który go nie wychowuje. W relacjach z innymi bohaterami przejawiają się elementy syndromu Dorosłych Dzieci Rozwiedzionych Rodziców ${ }^{6}$. Te prawidłowości można zauważyć zarówno w Złodziejach snów Strękowskiej-Zaremby, jak i w Yellow Bahama w prążki (2009) Ewy Nowak.

Znając typy bohatera sierocego, którego można napotkać w literaturze XX i XXI w., prześledźmy życie Juliany Dors, nazywając kolejne etapy.

Protagonistka rodzi się w 1939 r. w bieszczadzkiej, leśnej chacie, gdzie znalazło schronienie małżeństwo - Piotr i Magdalena. Związek był mezaliansem, na ślub nie zgodził się dziadek głównej bohaterki. Jego decyzja spowodowała ucieczkę młodych z podwarszawskiego Konstancina. Do siódmego roku życia Juliana dorasta w sielskiej atmosferze, nieświadoma zagrożeń II wojny światowej. W ten raj zło wdziera się najpierw za sprawą rzekomego księdza i wiecznie narzekającej Heleny, którzy znajdują tu — z dala od wioski — schronienie przed zagrożeniami konfliktu zbrojnego. Kolejnym gościem jest Ivan. Stanie się opiekunem dziewczynki po śmierci rodziców. Najgorszym intruzem okazują się banderowcy. Nie tylko mordują w bestialski sposób mieszkańców pobliskiej wsi, lecz także zabijają Piotra i dopuszczają się pobicia Magdaleny. O tragedii Juliana dowie się dopiero, gdy przeczyta dziennik matki - zatem w czasie choroby rodzicielki, życia w chacie z Ivanem i tułaczki „nie wie, że jest sierotą”. Przez większość czasu uważa się za „półsierotę”, zaś poszukiwanie ojca staje się niejednokrotnie motywacją do kontynuowania tułaczki i niepoddawania się przeciwnościom losu.

„Sierota wędrująca szuka” dziadków Brzeskich oraz swojego wuja — Stanisława, starszego od niej o trzy lata. Chce trafić do Konstancina. Jednak podróż komplikuje się już na początku. Dziewczynka wsiada do niewłaściwego pociągu i — zamiast do Warszawy — dociera do Krakowa. W czasie rozmowy ze współpasażerką przyznaje się, że nie ma mamy, a kobieta zostawia ją samą.

${ }^{6}$ Edyta Sokołowska opisuje zagadnienie oraz podaje bibliografię problemu w artykule Dorosłe Dzieci Rozwiedzionych Rodziców - przegląd teorii i badań, „Ogrody Nauk i Sztuk” 2013, nr 3, s. 109-122. Problem dotyczy spektrum działań, zachowań, lęków dziecka, którego rodzice się rozeszli. Syndrom jest jedną z najgorszych konsekwencji rozwodu — naznacza potomstwo piętnem, które musi być przepracowane, by córka bądź syn mogli założyć swoje rodziny i odnaleźć się w trudnej rzeczywistości. 
Pierwsze schronienie znajduje wśród zakonnic, stając się ,sierotą w domu dziecka". Traktują ją tutaj bardzo źle, dlatego planuje ucieczkę. Tu po raz pierwszy doświadcza przemocy fizycznej — siostra Benedykta dotkliwie karci ją za ubrudzony elementarz. Krótkie chwile szczęścia przypadają na pobyt w żydowskim sierocińcu. Panie Elwira i Nina wzorują się na pedagogice Janusza Korczaka. Dziewczynka uspokaja się, ma przyjaciółki, dobrze się uczy, otoczenie daje jej poczucie bezpieczeństwa. Ostoja zmienia się w miejsce wrogie wraz z nadejściem socjalizmu i początkami PRL-u. Kierownictwo placówki obejmują wówczas osoby, które promują rywalizację oraz usiłują wtłoczyć w młode umysły idee socjalistyczne.

Potrącona przez samochód trafia do szpitala, gdzie daje się zapamiętać dzięki swej uczynności i chęci niesienia pomocy innym chorym, a zatem „sierota przygarnięta pomaga". Los odmienia się dzięki koleżance z sali — Adeli, która poleca jej iść do Izabeli. Kobieta okazuje się kokotą. U niej uczy się asertywności i poczucia estetyki. Po aresztowaniu kurtyzany dziewczynka błąka się ulicami. Pomaga pijakowi, który z wdzięczności każe swojej żonie zaopiekować się małą. W mieszkaniu Pierków żyje biednie, lecz wspiera wszystkich, czym zaskarbia sobie sympatię otoczenia. Pewnego dnia w restauracji — miejscu pracy Danuśki, żony uzależnionego - wytworna kobieta wszczyna awanturę o to, że dziewczynka tam pracuje (pomaga kelnerkom). Kłóci się nie bez przyczyny — chce adoptować dziecko. Pamela Gryffin pokazuje jej życie rodzinne, wychowuje ją wedle własnego pomysłu, natomiast mąż Wilhelm rozpieszcza Julianę. Znów spokój zostaje zaburzony przez działanie aparatu państwowego — najpierw mężczyzna, później jego żona zostają aresztowani za niepopieranie działań władzy ludowej.

Protagonistka trafia do grupki „dzieci ulicy”, których celem jest przeżyć i nie dać się złapać. W gazecie pojawia się ogłoszenie o poszukiwaniu jej. By uniknąć powrotu do domu dziecka, wsiada do przypadkowego pociągu - do Torunia. Tym razem współpasażerka, matka czwórki dzieci, przygarnia ją, by była ich opiekunką. Józef i Bronisława nie dbają o jej wykształcenie, nie popierają chęci nauki, a o udział w jasełkach wybucha awantura. Dziewczyna rehabilituje się w ich oczach uratowaniem Antosia przed uduszeniem w wyniku zachłyśnięcia oraz ocaleniem całego rodzeństwa przed śmiercią w pożarze. Trafia do szpitala, aby wyleczyć oparzenia. Pielęgniarce Reginie Dąbek zwierza się, że nie chce wracać do Szewczyków, w związku z czym kobieta staje się jej nową opiekunką. Po jej śmierci piętnastolatka jedzie do Białegostoku, a stamtąd do Starej Łuplanki. Tam trafia do babki Oleny. U niej w końcu czuje się spokojnie i bezpiecznie, jest pewna, że poradzi sobie w życiu. Po zaklimatyzowaniu się rozpoczyna naukę w oddalonym o piętnaście kilometrów liceum. Wiedzie biedne, ale szczęśliwe życie, przyjaźni się z Jankiem Romańczukiem. Relacji tej nie chce jednak przemieniać w związek. Po wypadku szeptuchy zostaje jej uczennicą, opiekunka jest $\mathrm{z}$ niej dumna, a społeczność wsi zaczyna ją poważać. W tym czasie uświadamia 
sobie intuicję, która pomaga jej leczyć innych. Znachorka przekazuje jej wiedzę na temat fito- i fizjoterapii.

Dziewczyna odkrywa pasję zielarską. Po maturze chce się dalej kształcić, więc mimo protestów babki i przyjaciela wyjeżdża do Białegostoku. Zaczyna pracę w szpitalu jako salowa, w wolnym czasie zbiera i przetwarza rośliny, które stają się jej drugim źródłem utrzymania. Pewnego wieczoru nieoczekiwanie zostaje świadkiem zbrodni. Nie powiadamia o tym milicji, więc musi uciekać. W Olsztynie znajduje zatrudnienie — jest sprzątaczką w Wyższej Szkole Rolniczej, później bibliotekarką i korzysta z prawa do bycia wolnym słuchaczem. Tam przyjaźni się z Leszkiem, z którym dzieli pasję zielarską. Podczas wyjazdów i zbiorów roślin naraża się lekarzowi, którym okazuje się jej wuj — Stanisław Brzeski.

Życie dorosłe rozpoczyna małżeństwem z rozsądku z Abrahamem Rońskim. Przy nim spędza najszczęśliwsze lata życia. Z upływem dni małżonkowie zakochują się w sobie. Przygarniają Olę i Aleksandra, którzy pomagają im w gospodarstwie. Tymczasem protagonistka zakłada firmę produkującą wyroby zielarskie, a także wygrywa proces z Brzeskim. Idyllę przerywa wypadek, w którym ginie jej mąż. Kolejnymi mężczyznami w jej życiu są Wojciech Zagórski (drugi mąż) i Antoni. Ostatni kocha ją nieodwzajemnioną miłością, co nie przeszkadza mu z ukrycia chronić jej interesy przed komunistami. Pomagają jej również Marek Zawada (adwokat, morderca poznany w Białymstoku) oraz Leszek (kolega z uczelnianego Kortowa). Owocem krótkiego drugiego małżeństwa, zakończonego rozwodem, jest Joanna.

Juliana ostatnie lata życia spędza $\mathrm{z}$ córką $\mathrm{w}$ warszawskim domu. Umiera na grobie rodziców przy leśnej chacie. Trafia tam razem ze swym dzieckiem i Adamem. Po dotarciu okazuje się, że Teofila przemieniła to miejsce w bar. Staruszka nie wytrzymuje wstrząsu wywołanego tym odkryciem.

W następnej części przybliżymy relacje Juliany z innymi bohaterami oraz proces odkrywania jej tożsamości. Będzie to punktem wyjścia do badań nad dzieciństwem Dorsówny. Skorzystamy z dokonań children studies, których istotą jest zobaczyć dziecko i jego problemy, zrozumieć położenie młodego bohatera, poznać świat (tu: przedstawiony) z dziecięcej perspektywy ${ }^{7}$. Niebagatelną rolę w życiu małoletnich protagonistów odgrywa otoczenie i rodzina.

Aby opisać więzi dziewczyny z matką, należy cofnąć się do wspomnień Magdaleny (de domo Brzeskiej - co jest istotne w kontekście konfliktu ze Stanisławem). Do wieku dorosłego jest jedynaczką — nie brakuje jej niczego, bywa rozpieszczana przez ojca, obraca się w wyższych sferach. Służąca Felisia wyręcza ją i babcię protagonistki w czynnościach domowych. Przez to kobieta jest nieprzygotowana do samodzielnego życia. W podróż z Piotrem zabrała piękne suknie, lecz nie pomyślała o niczym przydatnym. Gdy uświadomiła sobie nieprzysto-

7 J. Sztachelska, „Dziwność” dziecka (rzecz o imaginarium społecznym), [w:] Children studies jako perspektywa interpretacyjna. Studia i szkice, red. J. Sztachelska, K. Szymborska, Białystok 2014, s. 53. 
sowanie do realnych trudów życia, chciała, aby jej dziecko zdobyło jak najwięcej umiejętności praktycznych. Pragnęła przekazać córce wszystko, co sama umiała. Przy czym nie była to tylko znajomość pisania, czytania, liczenia i wiedzy ogólnej. Starała się, by dziewczynka jak najlepiej potrafiła zaopiekować się gospodarstwem $^{8}$. W czasie choroby matki siedmiolatka uczy się samodzielności i bardzo przeżywa, gdy Ivan nie pozwala jej tulić się do rodzicielki. W ostatnich rozmowach $\mathrm{z}$ nią dowiaduje się, że najważniejsze jest, by nigdy się nie bała. Tak jak w utworach dziewiętnastowiecznych ${ }^{9}$, sierocie w czasie wędrówki towarzyszy „opiekuńczy duch matki”. Budzi w czasie ucieczki na wieś, ostrzega we śnie ${ }^{10}$, pomaga w czasie procesu z Brzeskim. Dziewczyna podczas pobytu u babki Oleny wielokrotnie czuje jej obecność i wręcz zaczyna się bać. Prosi, by dusza matki poszła do nieba. Wiele miesięcy później piosenka Fogga wyzwala w niej tęsknotę za leśną chatą i rodzicami. Poszukiwanie i zbieranie ziół kojarzy się dziewczynce z umarłą, wszak wielokrotnie robiły to razem. Twierdzi, że wszystko osiągnęła dzięki niej. Wspomnienie jej przywołuje też opieka nad krowami podczas pierwszego pobytu u przyszłego męża. Jednak przyznaje, że nie potrafi być kapłanką domowego ogniska - nikt jej tego nie nauczył. Boleśnie odczuwa brak czułości, w czym upatruje źródła problemów w relacji z córką i mężczyznami.

Joanna mówi wprost, że matka nie potrafiła wypełniać należycie swoich obowiązków, gdyż sama nie zaznała ciepła rodzinnego. Ponadto interesy pochłaniały Julianę bez reszty. Jednak nie żywi do niej żalu o to, docenia starania w celu zapewnienia im dobrobytu oraz to, że nauczyła ją życia. Wspomina, że większość czasu była pod czyjąś opieką. Najbardziej lubiła pobyt na wsi u Oli i Aleksandra, gdzie bawiła się z czwórką innych dzieci, a także u pana Leszka i jego rodziny. Podkreśla jednak, że brakuje jej czułości ze strony matki oraz długich rozmów czy rozpieszczania. Opuszczenie przez ojca w wieku niemowlęcym naznaczyło ją tęsknotą za męską opieką i dotykiem - przeżyciami charakterystycznymi dla „dziecka rozwodników”. Widać to podczas zabawy trzylatki z Antonim. Kobiety zbliżają się do siebie dopiero w czasie ostatniej wspólnej podróży. W końcu mają okazję do rozmów oraz długo tulą się na polanie.

Zajmująco przedstawia się relacja z Teofilą, wnuczką Brzeskiego. Jej matka umarła wiele lat temu. Zostały opuszczone przez ojca, dopiero w czasie akcji utworu kobieta go odnalazła. Nie potrafili jednak nawiązać kontaktu. Toffi zaczyna poszukiwania Juliany, bo taka była ostatnia wola zmarłej. Ma misję przekazania

${ }^{8}$ Jest to niezwykle ważne, gdyż dzięki temu może przetrwać wiele trudnych sytuacji wymagających od niej zaradności w czasie pobytu u kolejnych opiekunów oraz zaskarbia sobie miłość Abrahama.

${ }^{9}$ M. Jonca, op. cit., s. 276.

${ }^{10} \mathrm{~W}$ opiekę Magdaleny wierzy również Joanna. Zwierza się Adamowi, że babcia wiele razy wskazuje jej drogę i rozwiewa wątpliwości. Gdy wnuczka jej nie posłucha, zawsze źle na tym wychodzi. Ponadto uważa, że odnalezienie Juliany przez historyka także zostało spowodowane przez zmarłą. 
przeprosin od dziadka, co wypełnia już podczas pierwszego spotkania. Okazuje się to bardzo nieostrożnym działaniem. Juliana odtąd nigdy jej nie polubi. Relację komplikuje kradzież pierścionka oraz przemienienie chaty w bar. Ostatnimi słowami w tej relacji są: ,[w]ynoś się z mojego domu!"11 z ust staruszki.

W ich kontaktach zaskakuje to, że nie potrafiły odnaleźć wspólnego języka mimo podobnych doświadczeń — obie są ,dziećmi opuszczonymi”. Można zaryzykować stwierdzenie, że te postacie są z sobą skontrastowane. Spójrzmy na nie przez pryzmat toposu „stara kobieta i dziewczyna"12. Juliana - fizycznie podeszła w latach — w czasie wspomnień jawi się jako dziewczynka, później młoda dama. Jednak sierotka z opowiadań mówi językiem dorosłych, zna swoją wartość, jest zasadnicza i butna. Teofila natomiast nie zachowuje się jak dobra kobieta nie chce się z nikim wiązać (choć podobnie Juliana w jej wieku!), jest niezorganizowana, knuje intrygi i utrudnia życie wszystkim wokół. Przez wpadanie w coraz to nowe tarapaty, z powodu naiwności zakrawającej na głupotę, staje się postacią antypatyczną. Panie są dla siebie jedynymi krewnymi, jednak ten fakt nie wpływa na ocieplenie ich relacji.

Krótko scharakteryzujmy teraz więzi Juliany ze Stanisławem Brzeskim. Brat matki był trzy lata od niej starszy. Pierwszy raz spotkali się, gdy kobieta zbierała rośliny w wiosce pod Grunwaldem. Mężczyzna uważał za swoją misję życiową walkę z praktykami znachorskimi. Starał się utrudniać jej życie na wszelkie sposoby, jednak nie zapewniając potrzebującym opieki lekarskiej ${ }^{13}$. Pikanterii dodawał fakt, że chciał uczynić z niej swoją kochankę, czemu stanowczo się sprzeciwiła. Obydwie kwestie wpłynęły na napięcie ich relacji, czyniąc z bohaterki „niewinność uciśnioną"14. Kontakt urwał się, gdy w Kortowie Abraham skutecznie wyperswadował prześladowcy seksualną intencję działań. Problem powraca, gdy protagonistka upomina się o swoją część spadku. Lekarz okazuje się nieznanym wujem. Aby wyjść z twarzą z tej sytuacji, sprzedaje posiadłość w Konstancinie oraz wytacza siostrzenicy proces, który... przegrywa. Dopiero wtedy kobieta odzyskuje spokój ducha. Po latach antagonista nakazuje córce odnaleźć poszkodowaną i przeprosić w jego imieniu. Zadanie wypełnia wnuczka.

Protagonistka podczas swej życiowej drogi nie tylko szuka rodziny, domu i opieki, lecz także stara się rozwijać swój charakter, wiedzę i umiejętności. Warto w tym momencie omówić zagadnienie dotyczące tego, czy wyprawa w poszukiwaniu korzeni nie była tak naprawdę odkrywaniem własnej tożsamości.

11 E. Cielesz, Córka cieni. Burza przed cisza, Warszawa 2016, s. 299.

12 E.R. Courtius, Literatura europejska i łacińskie średniowiecze, przeł. A. Borowski, Kraków 1997, s. 110-114.

13 Omawiany problem podejmuje film dokumentalny Skalna ziemia (reż. W. Borowik, Polska 1956). Świadczy to o wadze kwestii rozpowszechniania wiedzy akademickiej i rugowania praktyk medycyny naturalnej.

14 M. Jonca, op. cit., s. 62. 
Po opuszczeniu leśnej chaty życie Juliany koncentruje się wokół odnalezienia dziadków i wujka, ale też ojca. Tułaczka staje się również drogą do ukonstytuowania się ,ja” postaci — jej tożsamości. Pytanie „kim jestem?” wiąże się u protagoniski nieodłącznie ze „skąd jestem?”. Dlatego głównym celem wyprawy jest Konstancin — dom rodzinny matki. Przemysław Czapliński ${ }^{15}$ stwierdza, że bohater niezakorzeniony jest najbardziej symptomatyczny dla współczesnej prozy. (Używanie tego terminu wobec Juliany jest uzasadnione - chata nigdy nie była formalnie własnością jej rodziny.) Natomiast jego niestabilność przejawia się w przechodzeniu przez wszystkie odmiany tożsamości. Protagonista jest zawsze „nie stąd”, czyli obcy dla ludzi, wśród których znajduje się w danym momencie, a zatem też dla miejsca. Poczucie bycia „nie u siebie” naznacza go piętnem braku poczucia bezpieczeństwa i zagubienia. Wszystkie te elementy ogniskują się w Dorsównie. Nieliczne momenty, w których zaznaje szczęścia, wiążą się zawsze z powtórnym zakorzenieniem, odnalezieniem tymczasowego miejsca w świecie. Rzeczywiście, jak pisze badacz, nowa ojczyzna staje się okazją, przyczyną wręcz, powrotu do „siebie”. Więcej — pomaga odnaleziona tam miłość. Można uznać, że kolejne miejsca, w których przebywa, nie tylko są przestrzenią, w której kształtuje swój charakter, uczy się nowych umiejętności, lecz także okazją do odkrycia swojego prawdziwego ,ja".

Poznanie siebie przez Julianę dopełnia się nie tylko w wędrówce po Polsce, ale finalizuje w trakcie wywiadów z Adamem. Dzięki nim bohaterka uświadamia sobie, jak kolejne wydarzenia wpływały na jej tożsamość. Amelia Krawczyk-Bocian definiuje pamięć biograficzną jako sferę przypominania, powtórnego przeżywania wydarzeń, które miały miejsce w życiu jednostki. Poszukiwanie ,ja” w czasie rozmów ma terapeutyczny wymiar. Jednak możliwe jest to tylko wtedy, gdy teraźniejszość dominuje nad przeszłością. Bohaterka chce opowiadać, co ma świadczyć o jej samoświadomości. Narracyjne spotkanie z historią tego życia ma sens i ogromne znaczenie dla danej jednostki, sprzyja także porządkowaniu doświadczeń. Zgodnie $\mathrm{z}$ opisem badaczki w proces opowiadania angażuje się również badacz narracyjny ${ }^{16}$. Natomiast Małgorzata Okupnik ${ }^{17}$ zwraca uwagę na to, że autobiografia — „opowiadanie własnego życia” — jest „formą uporania się z przeszłością” i — co dla nas jest cenne - służy również „tworzeniu spójnego poczucia tożsamości”. Autorka opisuje badania narracji autobiograficznych o utracie. Przeszłość (śmierć bliskich, odchodzenie kolejnych opiekunów, brak poczucia bezpieczeństwa wywołany kolejnymi zmianami) wywarła niebagatelny wpływ na Julianę, co odzwierciedlają bardzo szczegółowe opisy wydarzeń. Jed-

15 P. Czapliński, Wobec tożsamości: tożsamość i wolność, czyli bohatera nowej prozy portret zbiorowy, [w:] idem, Ślady przełomu. O prozie polskiej 1976-1996, Kraków 1997, s. 225-253.

16 A. Krawczyk-Bocian, Narracja jako spotkanie, „Przegląd Pedagogiczny” 2011, nr 1, s. $199-205$.

${ }^{17}$ M. Okupnik, Fenomen pamięci. O trudnościach badań narracji autobiograficznych o utracie, „Acta Universitas Lodziensis. Folia Sociologica” 2012, nr 41, s. 101-103.

Literatura i Kultura Popularna 23, 2017

(C) for this edition by CNS 
nak czytelnika zastanawia zbytnia wręcz spójność, brak powtórzeń, somatyzacji narracji czy fragmentaryczności. Zatem nie spotykamy się z ,ja melancholijnym”, tylko z przemyślanym konstruktem myślowym. Nie wydaje się, by postać wiele zapomniała, a przecież jest to ważny element higieny pamięci ${ }^{18}$.

Można to wszystko odnieść do Juliany. Nie można zapomnieć, że to dzięki konwersacjom z Adamem uporządkowała opowiadane zdarzenia. Świadczą o tym chwile wzruszeń czy nawet przerywanie wspomnień pod wpływem emocji. Rzeczywiście, spotkania są okazją do przepracowania trudnych doświadczeń. Owocuje to polepszeniem relacji z córką, nie tylko w rozmowie, lecz także we wzajemnym dotyku. Historyk też odczuwa skutki rozmów — angażuje się w życie kobiet i czeka na kolejne spotkanie — snucie wspomnień.

Jak można było zauważyć w części opisującej dzieje Juliany, historia Polski wywarła na nie znaczący wpływ. Czy protagonistka może być typem bohatera, któremu — według zamysłu autorki — przyszło żyć w XX i umrzeć w XXI w.? W tej postaci łączy się refleksja nad tożsamością z cierpieniem w wyniku wydarzeń, które działy się w świecie rzeczywistym ${ }^{19}$. Dors może być nazwana bohaterką „,z historią w tle”. W jej wspomnieniach i w pamiętniku Magdaleny matka Joanny staje się głównym pretekstem oraz motorem większości wydarzeń. Jednak sytuacja geopolityczna skutecznie uniemożliwia wspomniane „zakorzenienie”. Wdziera się wszędzie tam, gdzie czytelnik wypatruje gołąbka spokoju i stabilności. Nie tylko napad oddziału UPA, ale stalinizm, działania milicji, aparatu bezpieczeństwa i trudy PRL-u mają wpływ na jej życie.

Dzięki pracowitości i kolejno zdobywanym umiejętnościom Juliana może przeżyć, jednak cały czas towarzyszy jej poczucie obcości. Jedynie wśród babki Oleny i wieśniaczek czuje się „swoja”. Doświadcza tego, gdy dostaje od nich nowe sukienki, by koleżanki ze szkoły średniej jej nie wyśmiewały, i słyszy, że nie pozwolą, by kogoś z ich wioski tak traktowano ${ }^{20}$.

W kolejnej części niniejszego szkicu analizie zostanie poddana postać młodej Juliany w świetle badań children studies. Jest to dość młoda metoda badawcza, w Polsce rozpowszechnia się od $2012 \mathrm{r}$. Wtedy to odbyła się pierwsza konferencja poświęcona tego rodzaju interpretacjom ${ }^{21}$. Nurt ten w swej istocie jest hybrydyczny - korzysta z dokonań nie tylko nauk o literaturze czy dziecku, lecz także kulturoznawstwa, antropologii i innych dziedzin humanistycznych. Chce wyzwolić myślenie o bohaterze dziecięcym z ograniczeń perspektywy pedagogiczno-dydaktycznej. Owszem, dokonania np. Janusza Korczaka okazują się bardzo trafnym punktem odniesienia, jednak uniemożliwia on spojrzenie całościowe na młodych umiejscowionych w różnego rodzaju tekstach kultury. Głównym celem jest spojrzenie całościowe — z natury heterogeniczne. Dzięki temu obsza-

\footnotetext{
18 Ibidem, s. 105-106.

${ }^{19}$ M. Wołk, Próba antropologii postaci literackiej, „Teksty Drugie” 2004, nr 6, s. 91-97.

${ }^{20}$ E. Cielesz, op. cit., s. 57.

${ }^{21}$ Children studies jako perspektywa..., s. 8.
} 
rom eksplorowanym nadaje się nowe znaczenia, a epistemologie przenikają się 22 . Eklektyczność badań umożliwia odkrycie oraz przedstawienie niejednoznacznego charakteru dzieciństwa - zarówno w pięknej, pozytywnej odsłonie, jak i tej grzesznej, wręcz intrygująco-cielesnej ${ }^{23}$. Brakuje tu zatem kanonicznego obrazu młodego bohatera, co pozwala na uzyskanie świeżego spojrzenia, ale też znalezienie nowych sposobów mówienia o nim. Dziecko — złożone w swej prostocie — staje się nową gałęzią nauki humanistycznej.

Jednym z głównych postulatów jest przypomnienie, że utwory o młodych nie ukazują dzieciństwa takim, jakie jest naprawdę, ale jakim chcą je widzieć pisarze $^{24}$. Już to nakazuje traktowanie $\mathrm{z}$ dystansem wszelkim utworów, które nie są napisane przez małoletnich twórców; podaje w wątpliwość autentyczność rozważań pisanych z perspektywy dorosłego.

Jak już zostało powiedziane, w języku małej Juliany czytelnik zauważy niespotykaną dojrzałość, słowa nie mają nic wspólnego z mową dziecięcą, zadziwia pewność siebie i przekonanie o odpowiedniości podjętych działań — wręcz nie ma miejsca na wątpliwości na temat ich trafności. Dopiero w czasie opowiadania niejednokrotnie wzrusza się i przeżywa - na nowo, a może dopiero - trudne zdarzenia: „Juliana przerwała opowieść. Ukryła twarz w dłoniach i trwała tak dłuższą chwilę. Adam i Toffi nawet nie drgnęli, pozwalając jej na czas spóźnionej żałoby, której Juliana rzucona w wir wydarzeń, borykająca się z każdym kolejnym dniem, nie miała czasu przeżyć" ${ }^{25}$ czy „westchnęła, wstała $z$ fotela i podeszła do okna. Przez chwilę trwała w milczeniu" ${ }^{26}$. Te reakcje mają miejsce dopiero w życiu staruszki, dziewczynka opisuje zdarzenia, relacjonuje kolejne zmagania z losem, rzadko wtrącając ówczesne przemyślenia. Wspomnienia kobiety są bardzo szczegółowe, z detalami opisuje napotkanych ludzi i miejsca, w których przebywała. Zwłaszcza na początku wędrówki wszystko jest dla niej ciekawe, nowe, a zarazem lekko przytłaczające. Równocześnie przez odpowiedni dobór słów, sprawia wrażenie, że pamięta, jakie odczucia wywarły na niej poszczególne sytuacje. Napotkaną siostrę konsekrowaną opisuje następująco: „kobieta [...] zamiast płaszcza miała białą szatę i coś czarnego i długiego na plecach" ${ }^{27}$. Czytelnik domyśla się, że mowa o osobie w habicie zakonnym. Dalej mamy: „[n]ie potrafiłam uruchomić kranu i siostra zburczała mnie, że jestem brudas i nie wiem, do czego służy woda w łazience. Dzięki temu dowiedziałam się, że pokoik bez okien

${ }^{22}$ K. Szymborska, W metodologicznym tyglu Children Studies, [w:] Children studies jako perspektywa..., s. 25.

23 J. Sztachelska, op. cit., s. 50.

${ }^{24}$ K. Szymborska, op. cit., s. 25.

25 E. Cielesz, Obce matki, Warszawa 2016, s. 163.

${ }^{26}$ Ibidem, s. 164.

27 Ibidem, s. 180. 
tak właśnie się nazywa”28. Właściwie jedyne słowa charakterystyczne dla języka dziecięcego to „tatuś” i „mamusia”, określające jej rodziców.

Głównym problemem małej Juliany jest przeżycie i znalezienie ojca, może też rodziny. W czasie tej drogi zauważamy, jak powoli socjalizuje się, przystosowuje do życia w cywilizowanym powojennym świecie miasta i wsi. Jej rola społeczna długo pozostaje nieokreślona. Jedyne, co jest pewne dla kolejnych jej opiekunów, to konieczność kształcenia dziecka. Nieliczni zwracają uwagę na potrzeby ducha, dotyku, serdecznych uczuć, przyjaźni, nauki bycia przyszłą matką czy żoną. Realizuje się w niej fenomen dzikiego dziecka ${ }^{29}$ — w odpowiedzi na nie każdej „obcej matce” zależy na zakorzenieniu bohaterki w społeczeństwie, oswojeniu z jego zasadami i narzucanymi rolami.

Juliana w każdym nowym miejscu czuje się obca. Spotyka ją wykluczenie nie tylko z powodu sieroctwa, ale też bywa tak, że otoczenie boi się jej mocy korzystania z zielarstwa - dziecka „natchnionego" ${ }^{30}$. Brak normalnego dzieciństwa zauważa już Magdalena. Nie tylko dlatego, że dziewczynka nie zna przywilejów życia w mieście, lecz także z powodu braku ojca: „ta dziewczynka nic nie wie [...]. Moja mała dzikuska”31; ,,[p]rzeraża mnie przyszłość. Śmierć Piotra i moje kalectwo odebrały naszej córce szansę na beztroskie dzieciństwo"32. Można tu znaleźć również częsty w literaturze powojennej upadek mitu szczęśliwego dzieciństwa, realizację metafory kruchości ludzkiego życia ${ }^{33}$.

Inność protagonistki wynika z trzech przesłanek: fatalnych warunków społeczno-ekonomicznych większości miejsc, w których się zatrzymywała, oraz biedy jej samej; braku miłości, a także stałego miejsca zamieszkania, zwłaszcza w czasie życia na ulicy ${ }^{34}$. Pomimo trudnych emocji, z jakimi wiąże się wspominanie i przeżywanie przez to na nowo niefortunnych zdarzeń, przywołanie czasów dzieciństwa staje się kluczowe dla zrozumienia samej siebie przez Julianę oraz ukonstytuowania własnej tożsamości. Pośrednikiem zostaje jej język — już omówiony. Mimo wrażenia szczegółowości opisów powrót do czasów dzieciństwa jest możliwy jedynie częściowo ${ }^{35}$. Co więcej, nadmierna dbałość o szczegóły podważa autentyczność wspomnień, tak jak zbytnia dojrzałość i rozumienie spraw przekraczających możliwości poznawcze dziecka ${ }^{36}$.

28 Ibidem, s. 183

29 J. Sztachelska, op. cit., s. 52.

${ }^{30}$ M. Chrobak, Obcość jako kategoria interpretacyjna w badaniach nad dzieciństwem i literaturą dla dzieci, [w:] Children studies jako perspektywa..., s. 56.

${ }^{31}$ E. Cielesz, Siedem szmacianych dat, Warszawa 2016, s. 278.

32 Ibidem, s. 229.

33 M. Chrobak, op. cit., s. 58.

34 Ibidem, s. 63.

${ }^{35}$ M. Sowiński, K. Trzeciak, Reprezentowanie dzieciństwa w prozie polskiej po 1989, [w:] Children studies jako perspektywa..., s. 113-116.

36 Ibidem, s. 122. 
W ostatniej części tego szkicu przyjrzymy się teoriom Alison Landsberg dotyczącej „pamięci protetycznej” oraz memory boom w interpretacji Dawida Berlinera i Andreasa Huyssena. Wykorzystanie wymienionych badań motywuję budową omawianej trylogii — wspomnienia spisane w pamiętniku Magdaleny i przytaczane przez Julianę stają się główną osią utworu. Na potrzeby niniejszej pracy wydzielono dwa typy adresatów przypominanych historii: odbiorcę I stopnia (Adama - bohatera utworu, odtwarzającego wydarzenia na podstawie snutych rozważań) oraz odbiorcę II stopnia ${ }^{37}$ (czytelnika mogącego interpretować przedstawione opisy z szerszej perspektywy).

„Pamięć protetyczna” to wyobrażenie o przeszłości, której odbiorca nie przeżył samodzielnie, a jednak uświadamia sobie na podstawie informacji dostarczonych mu przez świadków wydarzeń. Wspomnienia te krążą w obiegu publicznym, są niezakorzenione w ciele, lecz doświadczane za jego pośrednictwem. Dane mają pochodzić z mediów dzisiejszej kultury. Najważniejsze jest to, że stają się częścią osobistego archiwum doświadczeń, odbiorca zaczyna uważać je za swoje, wpływają na jednostkę tudzież jej podmiotowość oraz relacje z teraźniejszością i przyszłością. Wspomnienia wydarzeń niedoświadczonych, podane w narracji ustnej, są dopełniane przez wrażenia zmysłowe. Interesująca wydaje się myśl dotycząca możliwości przejęcia wspomnień, co nie należy do naturalnego dziedzictwa ${ }^{38}$.

Pojęcie memory boom zawdzięczamy Andreasowi Huyssenowi ${ }^{39}$, który zwrócił uwagę nauk humanistycznych na problem rozpowszechnienia się w nich zainteresowania pamięcią, począwszy od lat 80 . XX w. Było to związane z koniecznością przepracowania traum dotyczących wojen światowych, Holocaustu i totalitaryzmu. Aktualna obsesja pamięci ma być znakiem kryzysu znormalizowanej struktury czasowości. Natomiast jej wyzwaniem jest „,zaproponowanie takiej ramy myślowej, która nie przeciwstawiałaby sobie jako nieprzekraczalnych opozycji i nie wykluczała wzajemnego przenikania się pamięci i amnezji" ${ }^{40}$. Celem tej mnemonicznej psychozy ma być utrwalenie każdego wydarzenia, każdej rozmowy czy przejawu ludzkiego życia. Mają temu służyć coraz nowocześniejsze i łatwiej dostępne media i urządzenia. Paradoksalnie, jednocześnie, bardzo eksploatowanym typem i coraz częściej ekranizowanym jest „bohater bez pamięci”, bez przeszłości, ofiara amnezji. Dawid Berliner zwraca uwagę na to, że memory

37 Jako odbiorca II stopnia relacji Juliany i Magdaleny potwierdzam oddziaływanie przeczytanej interpretacji wydarzeń historycznych zawartej w trylogii. Oprócz uświadomienia znaczenia tych katastrof dla indywidualnych ofiar oraz całych narodów zauważam tworzenie się wyobrażeń, które można nazwać pamięcią protetyczną. Abstrahuję w tym miejscu od kwestii warsztatu pisarskiego Ewy Cielesz.

38 A. Landsberg, Pamięć protetyczna, [w:] Antropologia kultury wizualnej: zagadnienia $i$ wybór tekstów, red. I. Kurz, P. Kwiatkowska, Ł. Zaremba, Warszawa 2012, s. 690-697 (pierwsza część rozdziału Prosthetic Memory, [w:] eadem, Transformation of American Remembrance in the Age of Mass Culture, New York 2004).

39 T. Skalska, op. cit., s. 1-8.

40 Ibidem, s. 3. 
boom ma źródło w antropologii — nauce badającej obecność przeszłości w teraźniejszości; jej obiektem jest człowiek żyjący w społeczeństwie w kontekście historycznej zmienności. Akcentuje on współistnienie, korelację pamięci i kultury. Wyodrębnia pamięć społeczną — falę nośną informacji przekazywanych indywidualnie i grupowo — oraz koncepcję pamięci zbiorowej ${ }^{41}$.

Odnosząc podane teorie do omawianego cyklu powieściowego, można założyć, że medium pośredniczącym w przekazywaniu wspomnień są dziennik Magdaleny oraz opowieści Juliany ${ }^{42}$. W czasie recepcji tychże treści nie tylko zmienia się wyobrażenie Adama o wojnie i PRL-u, lecz także wywierają one wpływ na jego życie. Reminiscencje stają się zarówno sposobem przepracowania przeżytych traum przez protagonistkę, o czym wspomina Huyssen, jak i medium, dzięki któremu historyk - odbiorca I stopnia - tak wczuwa się w usłyszane, przeczytane opowiadania, że zapomina o swoim świecie ${ }^{43}$. Natomiast wiedza akademicka zostaje skonfrontowana i uzupełniona przez świadectwa naocznych świadków. Przez to staje się pełniejsza. Wyzwalając się z ograniczeń czasoprzestrzennych, dzięki identyfikacji wizualnej, ma okazję odbierać bodźce i wspomnienia związane z sytuacjami, w których nie miał szansy się znaleźć. Można wręcz zaryzykować stwierdzenie, że świat kobiet z bieszczadzkiej chaty staje się dla niego alternatywnym. Tym atrakcyjniejszym, gdyż dostępnym tylko jemu.

Jednocześnie ucieleśnieniem tych ,jego — nie jego” wspomnień są kolejne wyprawy do miejsca narodzin protagonistki. Zarówno percypowane treści, odczucia i zjawiska związane z domostwem, jak i wspomnienia zasłyszane z ust własnej matki czy opowiadane przez ojca kolegi Marcina uświadamiają mu złożoność badanego zjawiska. Owocem tych doświadczeń są reportaże drukowane w czasopiśmie historycznym, dzięki czemu kolejne osoby mogą zbudować swoją pamięć protetyczną na temat wydarzeń wojennych. W końcu wspomnieć należy o specjalności Adama — historyk szuka śladów przeszłości w teraźniejszości, głównie w przestrzeni miasta. Jest zatem szczególnie uwrażliwiony na wymowę niemych świadków. Nie dziwi pietyzm, z jakim traktuje bieszczadzką chatę. Dla niego to takie samo źródło historyczne jak przekazy, podania czy inne teksty pisane. Tak samo ważne, a nawet cenniejsze ze względu na obecność świata nadprzyrodzonego, gdy stwierdza, że nadal czuje obecność Magdaleny i Piotra, gdy przekroczy próg ich domu. Podsumowując, należy stwierdzić, że wszystko, co może mu cokolwiek powiedzieć o historii rodziny Dors, wspomaga tworzenie jego pamięci protetycznej.

41 D. Berliner, The abuses of memory: Reflections on the memory boom in antropology, https:// muse.jhu.edu/article/178196/pdf (dostęp: 24.04.2017).

${ }^{42} \mathrm{~W}$ teoriach pamięci główny nacisk kładziony jest na odbiór treści za pośrednictwem kina. Jednak ze względu na reakcje, jakie opowiadania bohaterek wywołują u Adama, pamiętnik i wspomnienia można uznać za równoważne media.

43 A. Landsberg, op. cit., s. 692. 
Postać Juliany realizuje wiele typów zawierających się w motywie sieroty. W czasach dzieciństwa, młodości tuła się po Polsce i szuka nowego domu. Zależnie od etapu życia, w którym ją spotykamy, może egzystować w domu dziecka, pośród uliczników, pomagać i przemieniać tych, którzy zapewnili jej opiekę oraz znosić prześladowania antagonisty. Adam odnajduje staruszkę ok. 2010 r., gdy ta mieszka z córką. Mężczyzna nie tylko zyskuje w tej relacji wspomnienia — treść artykułów historycznych, lecz także pomaga w odbudowaniu stosunków łączących kobiety. Zawarte w postaciach różne motywy sprawiają, że trylogia staje się bogata $\mathrm{w}$ treści, zajmująca czytelnika. W protagonistce Cielesz doskonale widać plastyczność i płodność motywu sieroty - typy „wędrująca” oraz „opowiada” często są złożone, ale też generują następne kategorie. Wspomnienia Juliany odczytane przez pryzmat children studies wskazują na złożoność dziecięcego bohatera oraz rzadko niespotykaną dojrzałość. Ważną przesłanką jest osoba opowiadająca - dorosła, mówiąca z perspektywy lat i mająca poszerzoną świadomość w porównaniu z samą sobą w okresie dziecięcym. Chęć wyzwolenia się z jarzma obcości, inności często kieruje jej dokonaniami, a samo naznaczenie wpływa na relacje z innymi.

Nie mniej ważną postacią cyklu powieściowego jest Adam. Na podstawie poznanych źródeł, wysłuchanych opowieści i odkrytych miejsc tworzy swoją pamięć protetyczną dotyczącą wydarzeń II wojny światowej i epoki PRL-u, których nie miał szansy przeżyć.

\title{
Córka cieni - from orphan's typology and children studies to prosthetic memory and memory boom
}

\author{
Summary
}

In the article are discussed orphan's motif and its variants shown in a cycle of novels Córka cieni. There are presented variants with explanations. Afterwards their presence has been shown in curriculum vitae of a protagonist - Juliana Dors, in sequence of written relations with others orphans characters and abandoned children. In the second part there was considered if searching her paternity was searching of her identity as well. At last there were shown historic events in which the main character takes part with her family. The main character had historical background, but there was considered if she lived like every child and women of war in the Polish People's Republic. 